movement of their pectoral fins, and the re-entering of the gravel by the post-larvæ. This paper constitutes the most objective account of the early life of the trout yet available.

\section{Nigerian Vegetation}

IN a short memoir, under the above title, R. W. J. Keay has presented an outline account of the main vegetational types of the very considerable and varied Nigerian territory. His aim is to interest and instruct agriculturists, foresters, naturalists, educationists and others in the botany and geography of Nigeria, no general account of the vegetation of this region having hitherto been available. In this extensive region the vegetation ranges from wet rain forest to very dry thorn savannah, few single African countries presenting such a range of vegetational types. The author rightly reminds his readers that only a relatively narrow coastal belt is covered with rich rain forest, the greater part of the hinterland consisting of savannah. The latter is clothed in tall grasses during the rainy season but becomes bare and open during the dry season when the grass is burnt. The thorn savannah occupies only a small area in the extreme north, with the Sahara desert over the frontier still farther to the north. The forest regions are described under the headings of mangrove forest and coastal vegetation, freshwater swamp communities, and the lowland rain forest zone; the savannah regions are discussed under four different zones; and an account is given of the montane vegetation with special reference to the very interesting floristic region of Cameroon Mountain $(13,350 \mathrm{ft}$.). The results of various ecological studies have been worked into this, the second edition of this work. Some useful and interesting vegetation profile diagrams and a comprehensive, if as yet provisional, map of the principal vegetation zones are appended to the text. The memoir is published by the Government Printer, Lagos, Nigeria, and can also be obtained from the Crown Agents, 4 Millbank, London, S.W.1.

\section{Pathogens of the Sugar Maple}

A FURTHER paper in the extended series of studies in forest pathology in Canada is contributed by V. J. Nordin on the causes of decay in the sugar maple (Acer saccharin) in Ontario (Canad. J. Bot., $32,221 ; 1954)$. Decay results in appreciable losses in volume of sound wood. Seventy-four per cent of 606 sample trees had some measure of decay. Twenty-eight fungi were found to be associated with decay in living trees. The most important of these are Armillaria mellea (Vahl ex. Fr.) Quél., Polyporus glomeratus Peck, Ustulina vulgaris Tul., Fomes connatus (Weinm.) Gill., Hydnum septentrionale Fr., Corticium vellereum Ell. and Crag., Pholiota spectabilis Fr., and Fomes igniarius (L. ex. Fr.) Gill. Several species previously unreported in the literature were found to be associated with decay in sugar maple in Ontario. Armillaria mellea is the most serious buttdecay fungus and $P$. glomeratus is the most important trunk-rotting species. Frost cracks are the most important site of entry for fungi. Various discolorations occur in sugar maple. The average extent of decay in living trees is estimated according to the occurrence of sporophores of $F$. connatus, $F$. igniarius, $H$. septentrionale and $U$. vulgaris. The incidence and volume of decay increased progressively with age and diameter. One hundred and nine species of Basidiomycetes are tabulated as occurring on living and dead sugar maple in Ontario. This paper is illustrated by a large number of plates.

\section{Aboriginal Rock-paintings in Australia}

UNTIL quite recently there had been little evidence of aboriginal occupation in New South. Wales. Investigations by W. H. Kinsela in the area immediately south of Sydney and extending throughout the Illawarra coast and tablelands have shown that, besides the well-known kitchen-middens, there are several groups of rock-paintings (Aust. Mus. Mag., 11 , No. 4). In the Avon River valley, for example, one group of paintings contained many figures drawn in black, the dominant one being a woman with exaggerated breasts. Some others, including a wombat, were in red. Among the charcoal pictures is the realistic side-view of a human, in silhouette, with a genuine attempt to put natural shape into body and limbs. The paintings throughout the whole of this 'new' area of the South Coast tablelands are typical of the species, style and technique seen elsewhere in eastern New South Wales. There is, however, a marked absence of the mass-patterns of stencilled-hand paintings which are seen so frequently in Hawkesbury Sandstone areas north from the South Coast. The majority of the paintings visited are fairly faint, and difficult to reproduce by photography.

\section{Colonial Development Corporation : Report for 1953}

THE annual report and accounts of the Colonial Development Corporation for the year ended December 31, 1953 (pp. 50. London: H.M.S.O., $1954 ; 2 s$. net), records the initiation of five new projects, the abandonment of seven projects and the termination of the East African ramie investigation, the Kenya fish farms and the Vitingini lead investigation, leaving fifty continuing projects and investigations. Capital sanctioned increased from $£ 39,400,000$ in 1952 to $£ 43,512,000$ in 1953 , mainly for productive projects, of which agriculture, animal products, forestry and minerals now account for 54 per cent, or 56 per cent of the $£ 25,349,000$ employed, and several agricultural/forestry projects now in early phases of development will eventually need large expenditures to bring them to completion. A further substantial reduction in head-office administration costs was effected during the year, the United Kingdom staff being reduced from 248 to 183 and regional offices staff from 114 to 106 , but further reduction is unlikely at the present scale of operations. For most projects the local labour is fairly efficient, though in some areas it is low, due mainly to poor physique, malnutrition, debilitating diseases and lack of education. In agricultural research a panel of agricultural scientists established in London in March 1953, with Sir Charles Darwin as chairman, has been of great help, and the Corporation's experiences and problems are made known to those who allocate Colonial Development and Welfare funds for agricultural research, affording an indication of priorities in this field.

National Museum of Wales: Report for 1952-53

THE forty-sixth annual report of the National Museum of Wales, Cardiff, covering the year 1952-53 (pp. 63; from the Museum, Cardiff; 1953), is the first to appear in the new format. The smaller size is more interesting and handier and is to be commended as a type of production to be copied. It is 